\title{
Decoding 'Going into Trance' ritual in festivals of saint and mother goddesses temples in Vietnam: A philosophical assessment
}

\author{
Thi Thuc Nguyen - Truong Thi Thanh Quy ${ }^{1}$ - Huong Thi Lan Nguyen - \\ Nigina S. Babieva - Gulnara F. Ruchkina
}

DOI: 10.18355/XL.2020.13.03.13

\begin{abstract}
Spirit mediumship rituals are one of the forms of Shamanism, common to all peoples on the planet, which arose during the period of tribal society. Today, spirit mediumship rituals continue to satisfy the spiritual need of some segments of the society. As a form of folk belief, these rituals appeal to a majority of the Vietnamese people, often taking place during nation-wide festivals. Spirit mediumship rituals are not only for communicating with spirits. The Vietnamese people believe that the dead continue to live in the ultimate realm of bliss while at the same time following the lives of their loved ones here on earth. Spirit mediumship rituals contain a "yin-yang" narrative with strong affective significance. However, modern skeptics question the value and nature of the phenomenon (beliefs vs. superstitions). This paper argues that understanding the humanistic value of spirit mediumship rituals as well as deciphering the meaning of the layers of the phenomenon will help people to realize more clearly the underlying moral nature of their experience, as well as the ritual's historicalcultural value that is worthy of protection and preservation.
\end{abstract}

Key words: Spirit mediumship rituals, medium, psychic, trance incarnations, mother goddess worship

\section{Introduction}

No scientist has been able to either confirm or refute the existence of a supernatural force in the human soul so far. Epistemologically speaking, such undertaking is beyond the methodological limits of scientific scrutiny. (Valco, 2018: 3; Baron 2019) Thus, we are left with analyzing existing human experience, personal accounts, and relevant historical records that claim to possess 'revelatory' information. The phenomenon of spirit mediumship rituals may partially be attributed to the beliefs, allusions, superstitions, emotional, and spiritual needs of the indigenous people. All of these seem to have played a role in making spirit mediumship rituals into a popular practice of a significant number of Vietnamese people. These ceremonies are often held several times a year during ceremonial occasions and take place mainly at the Temples and Shrines of the Saints of the Four Palace Cult.

These spiritual rituals embody a very different philosophy of life, marked by a mythical understanding of nature and the human's place in it. It came to be known by several different names, such as Spirit mediumship rituals or Trance Incarnations, and contains many "mysteries." The popularity of these Spirit mediumship rituals seems to be on the rise among the public. However, its nature is still quite vague. The spirit mediumship rituals phenomenon is thus causing many debates on scientific forums. (Huwelmeier, 2019; Schwenkel, 2018) The skeptics and the critics point out that there is no rational substance to the rituals and that these practices are mere psychological and artistic representations of crowd superstition. (Nguyen et al., 2019) The Soviet

\footnotetext{
${ }^{1}$ Corresponding Author, Hanoi Medical University; e-mail: truongthanhquyhmu@ gmail.com
} 
religious scholar, X.A. Tokarev (1964: 330), for example, described Shamanism and spirit mediumship rituals as follows:

“... Spirit mediumship rituals are considered to be a way of communicating with the spirits in two possible ways: either the spirit enters the Dharma teacher (or into his disciples), or vice versa, the Dharma teacher's soul travels to the divine land. In fact, spirit mediumship ritual is a way of hypnotizing people around, and thanks to that, the dharma teacher not only forces the adoration and the ceremony to believe in the supernatural, miraculous abilities, but the dharma teacher often believes in that ability, so during the spirit mediumship rituals, he is in a state of illusion. In the opinion of many researchers, the spirit mediumship rituals of Shamanism are very similar to Hysteria mental disorder (episodes of sudden uncontrollable and inappropriate laughing or crying); Shaman dharma teachers are often "silly" people with this disease. The purpose of worshiping Shamanism is to treat and cure people or animals as well as to eliminate hazards and fortune-telling, or to ensure one's success in career."

The defenders point out to their cultural and historical value, as well as to the possibility that this phenomenon has more than a psychological basis and needs to be studied without prior scientific prejudice. The question regarding the true nature, meaning, and motivational/moral potential of the spirit mediumship rituals thus stays open.

Careful observing, documenting and analyzing the practices as well as the overall setting in the Temples and Palaces ${ }^{2}$ where these rituals take place provide us with sufficient data for making preliminary assessments. The Spirit mediumship ritual is a religious-cultural phenomenon at the center of which there is the multiple appearance of incarnation of the Four Palace Cult spirits into the bodies of the Medium or Psychic. In essence, this is a ritual to communicate with the gods through Shamanists (medium, psychic). ${ }^{3}$ People believe that the gods can enter into the body of the medium and the psychic, in order to restrain the evil spirits, cure diseases, land bless the gathered disciples. When the spirit enters the medium, the medium and the psychic are no longer themselves, but the embodiment of the god who enters them. Participants of these rituals further believe that "man is able to live on the efficiency of the superior principles, which is the Soul. And that is the principle of inferiority, which is the Live principle. People have three Souls, in which men have 7 Live principles, women have 9 Live principles" (Nguyen, 2018: 126). These Principles do not completely dissipate when people die but they last forever. Some principles are associated with the body, other with the ancestral tablets, and some principles are so to speak 'floating', without being anchored to one concrete reality. Moreover, the living and the dead are always closely connected. That is the reason why the ancestor worship and commemoration rituals emerged to commemorate and help the deceased. Most people believe that the spirits of the dead will always follow the lives of their loved ones. Therefore, when staging and invoking the spirits, the spirit of the dead can enter the caller to talk to a living relative. Through this yin-yang conversation, the living one will know the requirements of their deceased loved ones about their graves

\footnotetext{
${ }^{2}$ Tây Hồ Palace (Hanoi); Sòng Sơn Temple (Bim Son Town, Thanh Hoa Province); Phủ Dày Temple (Vu Ban district, Nam Dinh province); Temple of the Great Mandarin Hoàng Mười (Ha Tinh province); The Princess Xứ Temple (An Giang province).

${ }^{3}$ Shamanism is a primitive type of polytheistic religion with animistic beliefs, including the belief in the existence of immortal souls. Since the "Shaman" (magician) is at the center of religious activities such as healing, communicating with the gods, (etc.), it is called Shamanism. Shaman is the translation of the word Tungus, originally meaning the one who is excited, reeling and dancing, going into a trance.
} 
and the forms of required prayer. In return, the living can find out about their future destiny. Although the spirit mediumship rituals are an influential element within Shamanism, the nature of the phenomenon in this context bears remarkable differences. Shamanism is mainly focused on life after the person's death. In contrast, spirit mediumship rituals are directed towards life in this world, with very real-life aspirations and fulfillment of human desires. The inclusion and acknowledgement of such aspirations bridges mystery with real-life needs, which appeals to everyone of all eras.

Spirit mediumship rituals are considered typical for the Four Palace Cult in the North as well as in the South, regardless of the specific type of environment (plains, urban areas, mountains, coastal areas). Commenting on the origin of the Mother Goddess and Spirit mediumship rituals in his article The Mother Goddess and spirit mediumship rituals, professor Ngo Duc Thinh gives us the following details:

"The origin of The Mother Goddess and Spirit mediumship rituals of the Vietnamese people are in the North region, which appeared at the latest from the late Le Dynasty (16th century). Later it followed the footsteps of immigrants to the South region and the Central Highlands. Spirit mediumship rituals in the North are about classics, majesty, etiquette; spirit mediumship rituals in the South region, especially in Saigon, are more open, fun, and more folkish. In Hue, in addition to the conventional spirit mediumship rituals, there is also the collective spirit mediumship rituals, called Đồng vui (the Happy Spiritual Performance), especially on the occasion of the death anniversary of the Mother Goddess, Thiên Y A Na, and taking the holy communion of the Mother Goddess on the "Perfume River to Hòn Chén Palace" (Ngo, 2017).

The Trance Incarnations have both, a medium and a psychic. However, the proportion of the psychic's significance and ritual action accounts for the majority of the ritual. Moreover, "These people do not voluntarily become psychics or mediums, but most of them are forced to adopt this role due to their circumstances, their inner abilities, family heritage, or spiritual destiny. Those who have the 'spiritual destiny' but have not yet come forward to the Saints often suffer from illnesses, which is a 'yin' disease that cannot be cured by medicine; alternatively, they fail to do business well. Folk belief calls this phenomenon the 'Saint maltreatment,' that is, the one who is being illtreated by Saints. When going into a trance, they often recover and make a good fortune" (Ngo, 2017). The mood of the medium and the psychic is often very different from normal people; they are more unstable, volatile, assertive, and sensitive. Most mediums are more "feminine." Among the common folk, therefore, comments about people who behaved like a medium have been recorded from very early periods of Vietnam's history, e.g. "such medium-like one," "such psychic-like one" - all meant in a derogatory sense.

When a person has been "compelled by the Saints" to take part in an anual trance ritual (depending on the schedule, it took place especially on the occasion of tháng Tám giố cha, tháng Ba giỗ mẹ (August is the month of Father (Trần Hưng Đạo Saint) death anniversary, March is a month of Mother (Liễu Hạnh Goddess) death anniversary), the psychic and the medium must often conduct the spirit mediumship rituals. In such rituals, according to the traditional folk understanding, the Saints from different regions of the universe flew back into their bodies that served as medium.

\section{Research Scope and Method}

The article provides an overview of the spirit mediumship rituals, starting from answering the question: What are Spirit mediumship rituals in terms of their essence, meaning, and value? What kind of philosophical and religious/spiritual understanding of the world stands behind them? Who are the participants and what is the structure

XLinguae, Volume 13 Issue 3, June 2020, ISSN 1337-8384, ISSN 2453-711X 
and setting of these rituals? At the same time, it aims to decipher the meaning types of spirit mediumship rituals to prove that this is a religious and cultural phenomenon with special contributions to culture, morals, and spirituality of the people. They bring to the light the unique nuances of the worship of Mother Goddess in Vietnam, worthy of being regarded and protected as cultural heritage acknowledged by UNESCO as an intangible cultural heritage of humankind.

In addition to studying materials from monographs, the results of completed scientific studies, articles published in scientific journals, etc. the authors of the article attended and directly observed the actual execution of trances in several temples and palaces across Vietnam (the North, the Central and the South Vietnam). They interviewed experts in the field of religion, culture, and cultural management, as well as the very actors of the rituals - the mediums, the psychics, and the common participants of the trances. The conducted qualitative study (i.e., interviews) included local people living around the temples and palaces as well as the relics managers. This diversity of consulted sources was to ensure that we get the most accurate and truthful information and data included in the article to prove the scientific points of the article.

\section{Research Results}

\section{The order in which the gods are worshiped}

There are seven levels of deities, also called 'rows', within the mythical pantheon of the Mother Goddess cult.

1. The Mother Goddess: is a title or way of referring to a respectable woman (or mother). The Mother Goddess is one, but she incarnates into Three Mother Goddesses or Four Mother Goddesses who take over the existing realms of the universe: Thiên Phủ (Heaven), Địa Phủ (Earth), Thoải Phủ (Water) and Nhạc Phủ (Mountain and Forest). Under the Mother Goddess, the lesser gods are classified as Rows and Palaces. (Bachkhoatoanthumo, 2020)

The worship of the Mother Goddess is one of the Vietnamese folk beliefs which dates back very early in the concept of worshiping natural gods. Over time, the concept of the Mother Goddess expanded to include heroines - real women in Vietnamese national history. In the system of worshiping the Mother Goddess, the highest Mother is the Mother Thượng Thiên (Heavenly Mother) (sitting in the middle, in red shirt) she is the Goddess who created the sky, the master of cloud, rain, thunder, and lightning. The Mother Liễu Hạnh appeared around the time of the late Le Dynasty but quickly became a deity and was honored as the Heavenly Mother, worshiped in the center, dressed in red. The Mother Thượng Ngàn (on the left, in green) is the almighty reincarnation of The Mother Goddess that oversees the mountains and forests. The Mother Thoải (on the right, in white shirt) is a goddess who rules the rivers and waters. The Mother Địa (the Earth Goddess) is the land keeper (Giacngo, 2019).

2. The level of mandarins: this level includes the 10 Great Mandarins, called from one to ten, but the first five ones are the Five Great Mandarins, who are worshiped and often performed the spirit mediumship rituals, including the First Heavenly Mandarin, the Second Mountain Control Mandarin, the Third Water Court Mandarin, the Fourth Envoy Mandarin, The Fifth Patrol Mandarin. There are also the Sixth Mandarin, the Seventh Mandarin, the Eight Diem River Mandarin, the Ninth Mandarin, the Tenth Mandarin Triệu Tường. The Second Mandarin, Third Mandarin and Fifth Mandarin are those most frequently incarnated during the rituals.

3. The level of court ladies (the princesses): At present, there is no consensus on the number of court saints in the worship system of the Mother Goddess Four Palaces Cult, but according to folklore, the Four Palaces of Court Ladies include 12 goddesses: 
the first court ladies - the first divine princess ${ }^{4}$; the second court ladies - the mountain princess $^{5}$; the third court ladies - the third water princess ${ }^{6}$; the fourth envoy court ladies $^{7}$; the fifth court ladies of Lân stream (the fifth court ladies of Lân stream) ${ }^{8}$; the sixth court ladies - the mother of six palaces ${ }^{9}$; the seventh court ladies Tân La, the seventh court ladies Kim Giao ${ }^{10}$; the eighth court ladies - the eighth court ladies of mountain and forest ${ }^{11}$; the ninth court ladies - the ninth court ladies of nine planets ${ }^{12}$; the tenth court ladies Đồng Mỏ - the princess Mỏ $\mathrm{Ba}^{13}$; the youngest princess Bắc Lệ $\hat{e ̣}^{14}$; the court ladies Bản Đền - the princess Bản Đền ${ }^{15}$. Among the 12 saints, there are four court ladies who are the Special Envoys of the Four Mother Goddesses who are the most important and often go into a trance.

4. The level of princes: In the divine system of Three Palaces-Four Palaces, the Four Kings, also known as the Four Kings-Princes Huang, are male Saints under the ranks of the Five Gods and the Four Gods, and on the Four Divine Merchants and the Four Kingdoms. This includes ten names named in the order of princes from Princ Hoang Ca to Princ Hoang Muoi. They are the sons of Bat Hai Dong Dinh, being reincarnated

\footnotetext{
${ }^{4}$ Considered to be the embodiment of the First Mother, a monk, rarely going into a trance. The Lady Thuong's clothes are red, pink scarf and she often works in Phu Giay internal palace (Nam Dinh).

${ }^{5}$ According to folklore, she was the daughter of the Man family in Dong Cuong, whose name was Le Thi Kiem, the wife of Mr. Ha Van Thien, the Tay, was assigned to govern the area of Dong Cuong by the court. She is the reincarnation of the Second Mother. The Second Court Lady ruled 36 mountain caves. Her main temple is Dong Cuong temple.

${ }^{6}$ She was the embodiment of the Third Mother. Her main temple is in Rong Temple, Nuoc Temple, Han Temple (Thanh Hoa Province), the Mother Thoải Temple (Lang Son Province) and estuaries.

${ }^{7}$ The legend has it that she was the princess Chiêu Dung, who was a general of Hai Ba Trung, one of eight female generals. She is a vicar to the Mother Tam Tòa. Her temple is located in Phu Giay Temple (Nam Dinh province); Cay Thi temple (Thanh Hoa province); Thuong temple (Lao Cai province); Temple of the court ladies Đệ Tứ, Gia Lam District, Hanoi.

${ }^{8}$ She was originally a Nung person under Le Trung Hung dynasty. She guarded the forest gate Lan River by Hoa River. Her temple is located at the forest gate Lan River, Lang Son.

${ }^{9}$ She is the embodiment of the Mother Liễu. According to folklore, the court ladies Lục was the daughter of the Nung chieftain in Huu Lung, Lang Son; her mother was the Trần dynasty princess. Her temple is located in Huu Lung (Temple 94) Lang Son, Cay Xanh, Tuyen Quang.

${ }^{10}$ She was the general of Hai Ba Trung, her main temple is located in Tan La, Mo Bach, Thai Nguyen.

${ }^{11}$ She instigated a rebellion following Hai Ba Trung. Her merits are remembered and worshiped by people in many places. In addition to Tan La and Thai Binh, her temple also exists in Lang Son.

${ }^{12}$ She was a nymph in heaven who descended onto earth in Bim Son, Thanh Hoa, helping people in their daily struggles. Later, when she died, she became the court lady Ba, recording books at the Cửu Trùng Heaven Palace. She often dwells in trance when returning to temples in Phu Giay, Nam Dinh or Sòng Temple in Thanh Hoa. When going into a trance, she wears a red shirt (pink shirt).

${ }^{13}$ She is the daughter of the Chieftain of Dong Mo Land, very good at the sword, with merits to help the country fight its enemies. She often returned to go into a trance with a yellow shirt. Her main temple is located close to Chi Lang Gate, the place she held in the past - Temple of the court ladies Mười Đồng Mỏ or Mỏ Ba Temple, in Mo Ba Commune, Dong Mo Town, Lang Son.

${ }^{14}$ Originally a Nung girl in Huu Lung, Lang Son, raped by the enemy, she immersed herself into Bắc Lệ River. She was the embodiment of the Second Mother Thượng Ngàn. Her main temple is located at Công Đồng Bắc Lệ Temple.

${ }^{15}$ She was the embodiment of the goddesses, depending on the temple or locality she manifested. Because of this, she often wears flamboyant attire at the beginning of the year, wear pink scarf at the end of the year.
} 
in the form of a general with remarkable merits in Vietnamese history. However, when the medium - psychic sees suitable days to perform spirit mediumship rituals, there are three people who often descend to medium spirit rituals, namely Hoang Bo (Ba), Hoang Bay, and Hoang Muoi. Mandarins: Hoang Ca and Hoang Doi; Hoang Chin are only rarely incarnated. The mandarins: Hoàng Tư, Hoàng Năm, Hoàng Sáu, Hoàng Tám do not typically descend into the earthly realm.

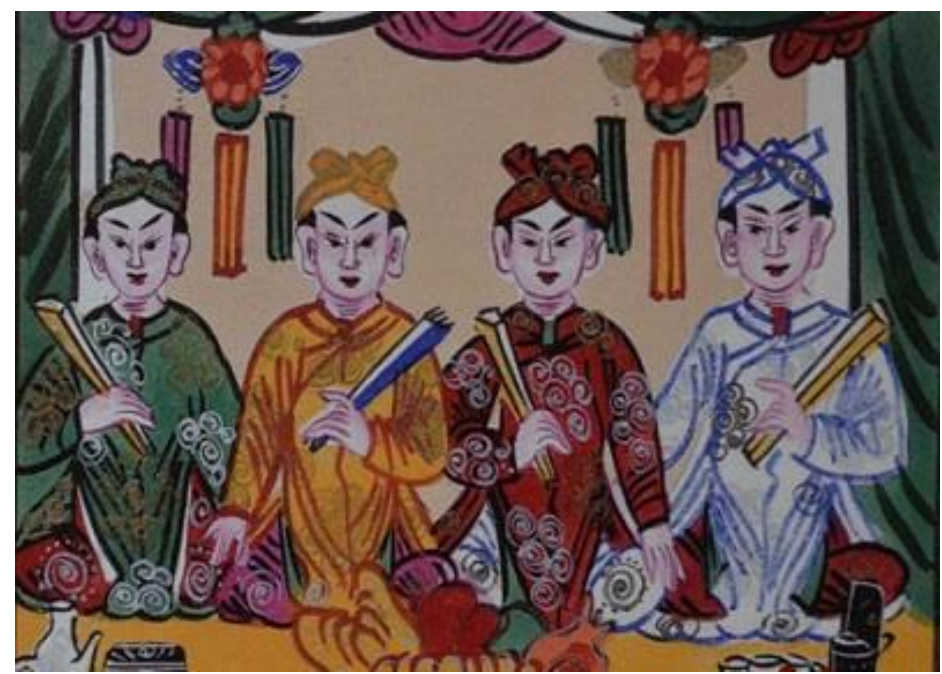

The Four Palace Saints, also known as the Ten Great Mandarins

[Source: Viet Theatre, "Thap vi Quan Hoang"; available at: https://viettheatre.com/blog/thapvi-quan-hoang]

5. The level of young princesses: This level includes 12 goddesses: The first princess Thượng Thiên ${ }^{16}$; the second princess Thượng Ngàn ${ }^{17}$; the third princess Thoải Cung (the princess Bơ Bông) ${ }^{18}$; the fourth princess Y La, the fourth princess Địa Phü ${ }^{19}$; the fifth princess Suối Lân ${ }^{20}$; the sixth princess Lục Cung, the sixth princess Sơn Trang ${ }^{21}$;

\footnotetext{
${ }^{16}$ She was the water of the Water King in Thoải Palace, and was named the Princess of Heaven Palace, the servant beside the First Mother. She is a wise, green, and gentle fairy, serving the Mother in Mẫu Sòng Sơn Temple.

${ }^{17}$ As the son of King Đế Thích in the Heavenly Palace, she was named the Princess Sơn Tinh. She was born in Ninh Binh land. The two main temples of the princesses Cô Đôi Thượng Ngàn are the two temples associated with her biochemical legend: Bồng Lai Hạ Temple in Nho Quan (Ninh Binh Province) where she was born; Bồng Lai Thượng temple (Cao Phong district, Hoa Binh province) is the place of incarnation.

${ }^{18}$ Like the son of the Water King in Thoải Palace, she was conferred as the Thoải Palace Princess. The princesses Bơ was born in the early Le dynasty. She had great merit in helping the King Le in the early years of fighting against the Ming aggressors. The princesses Bo is the main worshiper at the Princesses Bơ Bông Temple (Ha Son commune, Ha Trung district, Thanh Hoa province).

${ }^{19}$ Like the son of the Emperor Đế Thích chính cung, she also followed her father to serve the Mother Thượng Ngàn in Tuyen Quang land. She is worshiped in temples: Mother Ỷ La Temple (Tuyen Quang City) from a distance in Tu Lien communal house (Tay Ho district, Hanoi).

${ }^{20}$ She is a heavenly maiden descending to earth as a Nung ethnic girl in Lang region. Her sanctuary is now located right next to the main temple of the court ladies Năm Suối Lân (Huu Lung district, Lang Son province).
} 
the seventh princess Kim Giao (the seventh princess Tân La, the seventh princess Mỏ Bạch $)^{22}$; the eighth princess Đồi Chè ${ }^{23}$; the ninth princess Sòng Sơn, the ninth princess Thượng Ngàn ${ }^{24}$; the tenth princess Mỏ $\mathrm{Ba}$ (or the tenth princess Đồng Mỏ) ${ }^{25}$; the young princess Thượng Ngàn ${ }^{26}$; the young princess Thoải Cung. ${ }^{27}$

6. The level of young princes: including ten young princes, who are assistants of the Kings, but often descended as princ Bơ (Third princes) and princ Bé (Tenth princes)

7. In addition to the above-mentioned 'rows,' or levels of deities, there are also Snake Gods, and Tiger Gods also worshiped and often descending into the earthly realm. Like the Mother Goddesses, the aforementioned Gods are classified into four Prefectures: the Heaven Palace symbolized as red, Diagonal - yellow, Comfortable white, and Musical Cover - blue. In addition to the four above-mentioned governments, people sometimes mention Phu Tran Trieu (or Phu Nhan Than) worshiping Duc Tran and his subordinates. He is the god of a number of temples or worshiped at $\mathrm{Tu} \mathrm{Phu}$ temples in Vietnamese customs and traditions. He and his subordinates also occasionally infiltrated this realm to eliminate healing spirits. At times, the Holy Father was identified with the Jade Emperor and became the Jade Emperor of Vietnamese Taoism.

\section{Participants}

Regarding the composition to join a trance, the person who embodies the Trance Incarnations (collectively called Young psychic) has the most important position. In "Quốc Quốc" it is written that "In ancient times, only a person with the spirit of concentration, wisdom, purity, and nobleness would be able to descend into his body, so that he could become the intermediary connecting him with God. People like this are called "Medium" for a man and "Psychic" for a woman." (Nam, 2018) The Medium (Dong) has two or four sub-uniforms (known as two pillars or four pillars of surges). They follow a Young psychic to prepare uniforms and ceremonies.

Individuals who get into a trance are often said to be predestined, with a karma related to the Holy. Depending on karma, according to a predestined relationship, they can come to the Four Governments. But in order to become a young psychic, they had to go through an open-court ceremony under a co-teacher. Also, according to karma, they become one of the four forms: Missionary education; Merit of good deeds;

\footnotetext{
${ }^{21}$ She was honored as a fairy who has the ability to cure. Currently, the temple of the princesses is built next to the palace of the court ladies Lục Cung Nương (Chin Tu, Huu Lung and Lang Son).

${ }^{22}$ A fairy from the Moi ethnic group at Kim Giao temple, Mo Bach, Thai Nguyen. The princesses Bay is worshiped at the temple of Kim Giao (Thanh Lien, Mo Bach, Thai Nguyen) and also at Tan La Temple (Doc La, Bao Khe, Hung Yen).

${ }^{23}$ Said to be born in the Le Thai To Dynasty, she was instrumental in helping the king in his quest to fight off foreign invaders. The princesses Tám Đồi Chè is worshiped separately at her temple in Phong Muc, Ha Trung district, Thanh Hoa province.

${ }^{24}$ A nymph on the Heavenly Palace, the attendant of the court ladies Cửu - the Mother Cửu. The princesses Chín is the main worshiper at Cô Chín Sòng Sơn Temple (Bac Son Ward, Bim Son Town, Thanh Hoa Province). Besides, she is also worshiped in most temples, palaces in separate altars or shared in the Four Palaces of the Goddess.

${ }^{25}$ The princesses Mười Đồng Mỏ followed and served the court ladies of Mười Mỏ Ba, helping the king fight the $\mathrm{Wu}$ invaders. The divine relic related to princess Mười is almost nonexistent.

${ }^{26}$ Cô Bé Thượng Ngàn (the youngest princess from the mountains and forests) is a fairy whose name is often named after places and temples. All of the youngest princesses are goddesses in Son Trang Palace, in the form of Thuong Ngan. There are many girls all over the woods, big and small.

${ }^{27}$ She dwells in the palace Thoải Cung; she is very beautiful, talented, can chant the rain and call the wind ... The divine relic related to her has not been collected yet.
} 
Rescue salvation (co-moving, co-method, co-fortune telling, co-cure); Chief Justice Dharma. In particular, the group of teachers related to "Saving the family" is now very popular and well known in society.

Music is an indispensable component of the ritual and the composer (main palace) serves at the ceremony. The text from "Quốc Quốc," pertaining to the sacrifices conducted at the beginning of the Zhou Dynasty, states that "...Dance music can really touch the Spirit of the world, personally come to receive the sacrifices; this is also the power of the early dance music through God. Dance music can be performed through God, the Christmas God. For this reason, it is widely used for sacrifices and it developed into the Trance Incarnations dance."

In Vietnam, according to historical records, the song Chầu Văn emerged earlier than other types of folk songs. In the book, Small Notes on Witnessing and Hearing, scientist Le Quy Don notes that "The Tran dynasty (1225-1400) had a singing style in front of the Emperor, called Chầu singing." (Le, 2019: 145) Thus, it can be seen that Chầu Văn was used as a royal art form. Due to the history of the country tormented by chaotic wars it is now difficult to find the original source of Chau Chieu song and to determine the course of its development process, including the time since when it was put into use for chanting Trance Incarnations.

This opinion was also mentioned in the article "Chầu Văn - a form of worship of the Mother Goddess," by the musician Dân Huyền (Dan, 2016). Dan argues that "Chầu Văn originated from ancient folk beliefs when people believed in the presence of gods and fairies who served the Jade Emperor - the Maker of heaven and earth. They divided the world into three precepts: Heavenly Family, Hades, and Waterworld. Each precept has its own deity. Their duty is to protect humanity against all disturbances of youkai. The regular contact between "the naked" and the gods must be through intermediaries such as the Taoist, the witch, the medium, and the core. Those sitting in the audience come here to pay homage to the Saints, hoping to be in harmony with the dance and the blessed Saints. The most prosperous period of chầu văn singing is at the end of the 19th century and the beginning of the 20th century, when the world recognized it as a unique type of Vietnamese folk beliefs and culture, clothed into the words of spiritual music.

\section{The order of a trance}

Whenever a saint enters, it is through a trance. In the ball maid ritual, there is an estimated number of up to 36 trances. There are 36 trance Incarnations commonly referred to in the folk traditional belief. ${ }^{28}$ But in practice, the 'enterment' ritual depends on the number of trances and the number rarely goes up to 36 trances.

\footnotetext{
${ }^{28} 36$ trances including: Holy incense inviting Buddha, 2. Inviting the Mother, 3. Monarchist, 4. The highest rank Great tutor, 5. The first great mandarin, 6. Inviting the second great mandarin, 7. The third civil mandarin, 8. Inviting the fourth mandarin, 9. Patrolling great mandarin, 10. Great mandarin of Reigning king's court., 11. The first court ladies, 12. The second court ladies, 13. The third court ladies,14. The court ladies of Great Ba God, 15. The court ladies of Thác Bà Goddess, 16. The fourth court ladies, 17. The court ladies of Bắc Lệ God, 18. The court ladies of Mười Đồng Mỏ Saint, 19. The court ladies of Bắc Lệ princesses, 20. Inviting the princes Hoàng Cả, 21. The civil mandarin Hoàng $\mathrm{Ba}, 22$. The civil mandarin Hoàng Bẩy, 23. The civil mandarin Hoàng Mười, 24. Inviting the first great princesses, 25. The civil mandarin of the princesses Đôi Thượng, 26. The civil mandarin of the princesses Đôi Thoải, 28. The civil mandarin of the princesses Năm Suối, 29. The civil mandarin of the princesses Sáu Lục Cung, 30. Inviting the princesses Tám đồi chè, 31 . The civil mandarin of the princesses Chín, inviting the princesses Mười, 32. The civil mandarin of the princesses, 33. Inviting the great princes, 34. Inviting the great princes Hoàng đôi, 35. Inviting the great princes Hoàng ba, 36. Inviting the great princes Hoàng bé.
} 
When practicing a ritual, any trances are performed by the assembly in a certain order. Formally, the trances basically perform the same sequence. The order of performing trances not only reflects the well-being, solemnity, and belief in a spiritual bond between the negative and the positive realms of a connection in a certain sacred space, but also between the dead and living. Interestingly, the mortal and the underworld has the same direction toward the common good. The sequence of a trance is described in some published documents and articles (TuPhu, 2018). Our actual research process also brings consistent results concerning the three fundamental components of a trance:

(1) Preparation of a scarf and a dress: This is the first stage and is done after the altar preparations are finished. At this time, the palace starts singing. The Medium or the Psychic start to wobble, making hand signs while keeping her face covered with red cloth.

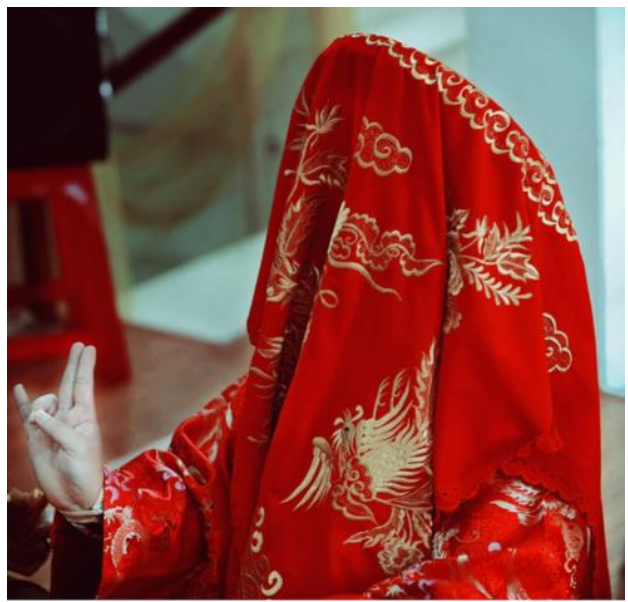

Putting the red cloth on a young psychic before the incarnation

[Source: Tue Minh, Mediumship rituals in Mother Goddess worship of ancient Ha Noi, https://baophapluat.vn/ha-noi-hotnews/tuc-thi-me-dong-quan-cua-nguoi-ha-noi-xua-469902.html]

The invitations to enter the Saints are provided with the singing in styles suitable to the trances. When the Saint has entered, the Young psychic wipes his face off as if it were the beginning of his return. If the saint just passes through, he/psychic makes another sign. The ceremony changes back to singing to invite the next person to come in. After throwing a towel, the Medium/Psychic is in a new "trance" and must change her clothes again. New towels, fan flags, and servants come to the scene to match this new "trance." According to our observation, we found that for the Quan and Hoàng trances, the Young psychics often dressed in the mandarin's robes of the ancient times, having jewelry points such as brooch, ivory card, pomp, etc., then dressed neatly in the style of rich, colorful women, adorned with many jewels to make her look more youthful. During the You Trance, the psychic is dressed as a young man, wrapped with towels.

(2) Ceremonial dance: After getting dressed, the Saint began to stand up for the ceremony. Young psychic must hold incense through a layer of red cloth to offer to the altar of The Mother Goddess. She kneels for the ceremony and then goes out to the audience to perform other rituals, mainly dances by trance. 


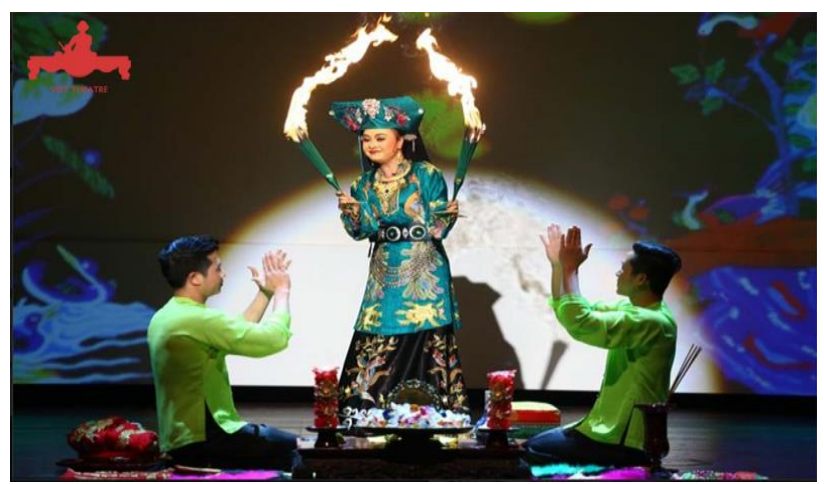

A scene from the ceremony of Trance Incarnations was recreated on stage of Four Palaces Cult. The show was directed by Viet Tu and Viet Theater

[Source: Viet Theatre, General guidelines of Hau dong; https://viettheatre.com/blog/huong-dancach-hau-dong-va-cac-nguyen-tac-chung-trong-nghi-thuc-hau-dong]

The dances belong to one of the following levels:

- Level of mandarin: Flag dance, sword dance, long sword, defoliant;

- Level of court ladies: Primer dance, flag dance, sword dance, fan dance, bare hand;

- Level of princes: Cheo Dance, flag dance, sword dance;

- Level of young princesses: Rowing boat, market dance, brocade weaving and dance like those of Chầu trance;

- Level of young princes: Sword dance, Unicorn dance.

There are many researchers who believe that the dances performed by Young psychics in trances not only show the joy of doing the Holy work or having fun with the audience, but also manifest the dread caused by the power of the Saint God. While the Young psychic was reincarnating, the four subordinates sat down on their knees, facing the audience. The participants also tilted and danced in response to Young psychic to the rhythm of the song. Accompanying the dance is the free distribution of the small change of psychic money tossed tot the participants by Young psychic. She throws this money to people as a ransom. The banknotes are quickly picked up by the people and stored for luck.

It is difficult to establish how the Trance Incarnations dance developed and what specific forms of dancing it copied. Some examples have been preserved in museums. Each type of dance represents a specific type of activity and native environment of Vietnamese people. We may conclude that activities such as dances, rowing flowers, and sword dancing were designed, among other things, to manifest clearly the Vietnamese women's character.

(3) Propagation and sublimation: After the "sublimation" period, the Saint was entering into a medium/psychic body, sat down, listened to songs, and drank betel nuts. When one drinks alcohol, the companions must cover their faces with fans as if creating a separation between the Spirit and the world. While listening to the text, the saint did the remaining procedures, such as clearing and speaking. The narrative about pre-logistics, post-logistics, and demolition rituals reassured the disciples. After that, the Holy Council signaled, and a red scarf was used to cover up the psychic. This marked the official closing of the Trance Incarnations.

\section{The significance of the spirit mediumship rituals phenomenon}

When observing the phenomenon of spirit mediumship rituals, we realize that these rituals represent layers of profound human aspirations. Three approaches to meaning can be identified in them: 
(1) An embodied, dramatic way of explaining meaning: The rituals use appropriate symbols to communicate the presence of the Holy Spirit, i.e., the spirit of the Mother Goddess in her various manifestations, to the communicants. The communicants are all people present in the ritual who are 'touched' by the sensual and mystical experience of the ritual made possible by the intermediary, namely the spiritual medium in the person of the psychic/medium. The established use of symbolic artefacts and colors (red symbolizes the sky; yellow symbolizes the landscape of the fields; white is the color of the rivers and the sea; and blue is the color of the mountains) helps participants identify precisely what is going on in the ceremony. Meaning is thus conveyed not primarily through the mythical narratives that have been handed down through generations, nor via the content of the accompanying chants and songs, but rather 'procedurally' - by enacting episodes of the mythical encounter of the gods with nature and the people. This episodic, procedural knowledge is highly participatory and engaging. It does not flatten one's identity to that of a 'rational animal' (the intellectualist approach) but rather invites the believers experience the drama by enacting and reliving the stories of trance incarnations. Meaning is thus not 'explained'; it is dramatically enacted.

(2) A way of social manipulation of meaning: Though it is primarily a rite of the Holy Spirit with profound spiritual and moral significance, the ritual also reveals and reinforces an existing social structure through the lens of "ritual." In the content and enactment of the ritual, we can see not only the relationship between human individuals and the spirit but also the way human beings are governed and dominated. The present social order emerges organically out of this dynamic mythical drama, performed always anew to reinforce the dominant social hierarchy and rules of interhuman relationships. Heaven reaches down to earth to mold it by infusing its presence among the people, using specific incarnations of the divine. This dramatic, ritualist 'manipulation' of reality is very potent in shaping the moral and spiritual imaginations and creating ethical and social imaginaries of the Vietnamese folk. It is a fluid, dramatic, ritualistic philosophy of life - acted upon the participants and with the participants, rather than abstractly, intellectually mastered. The specific structure of the divine society is reflected in the social structure and obedience models here on earth and experienced ritualistically, which then gives the ground for the individual to process this experience cognitively.

Another important aspect consists in the fact that when a person of a young age and from a low social class becomes the medium of the Spirit, even people of an older age and much higher social status must worship the medium and ask for advice. This context-induced spiritual reality trumps all existing, temporary social structures and exposes all participants equally as equally wanting, deficient, and hungry for meaning and guidance.

(3) A way of seeking a deeper meaning of one's existence: Spirit mediumship rituals and attending trances can be some of the most emotional and existentially relevant experiences that occur in an individual's lifetime. Time passes differently during the drama of the ritual. The person is pulled into a parallel time reality where time transpires at a different qualitative level. It is not just a matter whether it is faster or slower - it is more intense and personal, while giving the experiencing subject the opportunity to be completely immersed in the dramatic rendering of the events. His mind and soul is refocused in the ritual, so as to enable him to reflect deeper about his life priorities, goals, principles, etc. This an important asset for everyone, but especially those living in the context of a market economy, in an increasingly urbanized society. This experience provides a relief of tensions and frustrations because the spirit mediumship rituals help the worn out, neglected, or psychologically unstable individuals to reintegrate into the community. (Cao, 2020) The mental recalibration takes place alongside the touch of the divine spirit in the 
psychic/medium on a deep psychological level. Believers would call this a kind of spiritual renewal on the level on one's soul. Thus, at the end of the trances, every disciple feels reassured, strengthened in his belief in life, and has a new perspective on his place and role in the world.

\section{Conclusion}

The Vietnamese cult of the Mother was officially recognized by UNESCO and put on the list of Intangible Cultural Heritage of Humanity in 2016. As a native belief, the Vietnamese custom of worshiping the Mother Goddess, rooted deeply in the most ancient Vietnamese cultural and religious history, contributes to the beauty of Vietnamese culture, the psychological and spiritual well-being of participating individuals, as well as the cohesion of the Vietnamese society.

Spirit mediumship rituals are a form of practice that synthesizes almost the full value of this type of belief. The Mother Goddess is represented everywhere, in all three realms of the world - (1) heaven, (2) water, and (3) fields and mountains. The essential idea of these rituals is that the Goddess is not far away from the complexities of human life, but rather always close, always ready to be incarnationally represented in saints and heroes of this world. An example of such incarnational manifestation is Lieu Hanh, a heavenly nymph who upon becoming incarnate lived as a Buddhis nun and helped people. The daily worship is meant to draw the worshipers into a participatory encounter with these spiritual realities through carefully designed ceremonies, music, drama and art.

Decoding the spirit mediumship rituals phenomenon through the specific content presented in this study has the potential to help people better understand this phenomenon, which consists of a typical and unique model of worship and religious belief in Vietnam. This mystical worship experience aims at instilling a sense of honor and self-awareness in each participant, connecting them spiritually and culturally with the rich heritage of this Southeast Asian nation. The preservation and protection of one's soul happens ceremonially and intra-psychically (initially) through the experience of participation. To be effective, the ritual requires the contribution of various people with designated roles. However, it is the inner disposition of the participants that receives that which is symbolized in the manifold 'incarnations' of the Mother Goddess. Nevertheless, the ritual can speak even to a distanced observer who participates in the ritualistic worship out of curiosity, namely through its rich cultural content and historical value.

It is only natural, therefore, that it is in the interest of the Vietnamese society to preserve this cultural phenomenon. Many entities such as managers, researchers, artists, and others, should converge their energy in helping to preserve the cult of Mother worship. The main reason behind the need of such concerted effort is the fact that the knowledge, customs, and skills are transmitted orally, not in a written form. The practice of shared values and heartfelt beliefs in the compassion and grace of the Mother Goddesses, as it was transmitted and enacted through centuries, constitutes a fertile environment for the emergence of community cohesiveness and the strengthening of national/cultural identity. This has been happening not merely in Vietnam but also among Vietnamese emigrants. "Through their shared devotion to holy mothers, these Vietnamese American faithful have also rebuilt relations with coethnic co-religionists living throughout the world." (Ninh, 2018: 223) Another important consequence of this phenomenon is that it promotes the value of women and their indispensable roles in society. (Cline, 2010) Thus, it helps cultivate a new, philosophical-ethical perspective that is conducive to justice and equality across genders and social classes, as has been proven by numerous studies on the influence of religious beliefs on civic virtues. (Zalec, Pavlikova, 2019; Truong, 2020) Such new philosophical outlook needs to be further cultivated through ongoing educational efforts and mass media. 


\section{Bibliographic references}

BACHKHOATOANTHUMO. 2020. Len dong [Ritual]. Available online: https://vi.wikipedia.org/wiki/Len_dong

BARON, C. 2019. The Rise, Fall and Resurrection of (Ideological) Scientism. In: Zygon ${ }^{\circledR}$, vol. 54, n. 2, pp. 299-323.

CAO, T.H. 2020. Corruption and the Building of a Developmental Government in Vietnam Today: Social and Philosophical-Ethical Considerations. In: European Journal of Science and Theology, vol.16, n.1, pp. 51-68. ISSN 1337-8384.

CLINE, E. M. 2010. Female spirit mediums and religious authority in contemporary southeastern China. In: Modern China, vol. 36, n. 5, pp. 520-555.

DAO, D. A. 2018. Lich su Viet Nam - Tu nguon goc den the ky XIX [Vietnam's history - from its origins to the 19th century]. Ha Noi: National culture Publishing House. ISBN. 8935236412353.

DAN, H. 2016. Chau van - mot hinh thuc trong tin nguong tho dao mau [Chau Van" a form of belief in the worship of Mother Goddesses]. Available online: https://dantri.com.vn /van-hoa/chau-van-mot-hinh-thuc-trong-tin-nguong-tho-daomau- 20161202105912976.htm

DO, T. H. 2005. Confucius (translated version). Ha Noi: Culture and Information Publishing House.

FRAZE, G.J. 2007. The Golden Bough. London: MacMillan.

GIACNGO. 2019. Giac ngo online [Enlightenment online]. Available online: https://giacngo.vn /PrintView.aspx? Language=vi\&ID =76D40B

HOANG, T. X. (Ed). 2003. The Ten Religions of the World, Chapter VIII, Buddhism. Ha Noi: National Political Publishing House.

HUWELMEIER, G. 2019. Spirit writing in Vietnam: Political lessons from the beyond. In: The Asia Pacific Journal of Anthropology, vol. 20, n. 3, pp.278-293.

NGO, D. T. 2017. Dao Mau va len dong [Plagiarism and Spirit mediumship rituals]. Available online: http://daomauvietnam.net.vn/tin-tuc/dao-mau-va-len-dong/

NGUYEN, Q.H. - KOSARENKO, N.N. - KHAIRULLINA, E.R. - POPOVA, O.V. 2019. The Relationship between the State and the Catholic Church in Postcolonial Vietnam: The Case of Christian Village of Phung Khoang. In: Bogoslovni Vestnik, vol. 79, n. 2, pp. 521-533. ISSN 1581-2987.

NGUYEN, T. T. 2018. Religious Studies and religions in Vietnam. Ha Noi: Religious Publishing House.

LE, N. H. 2001. Vietnamese Folk beliefs. Ha Noi: Information and Culture Publishing House.

Le, Q. D. 2019. Toan Viet Thi Luc. Ha Noi: Literature Publishing House.

LE, T. K. 2018. Lich su Viet Nam - Tu nguon goc den giua the ky XX [Vietnam history - from origins to the middle of the $20^{\text {th }}$ century]. Ha Noi: World publisher. ISBN. 8935235223295.

NAM, P. 2018. Hau Dong, Len Dong. Su that ve mot tin nguong dan gian dang bị loi dung. [Hau Dong, Len Dong. The truth about a folk tradition is being taken advantage of, disguised]. Available online: https://www.dkn.tv/goc-nhin-dkn/hau-dong-lendong-su-that-ve-mot-tin-nguong-dan-gian-dang-bi-loi

NINH, T. H. 2018. Holy Mothers in the Vietnamese Diaspora: Refugees, Community, and Nation. In: Religions, vol. 9, n. 8, p. 223-248.

RAYMOND, A. M. J. 2008. Life after Death. Ha Noi: Labour Publishing House.

ROSEMARY, E. G. 2005. Religious Dictionaries and Transcendental Experiments. Ha Noi: Religious Publishing House.

RICHARD. H. 2018. Luoc su ton giao [Religious history]. World publisher.

SCHWENKEL, C. 2018. Religious Reassemblage and Late Socialist Planning in Urban Vietnam. In: Journal of the American Academy of Religion, vol. 86, n. 2, pp. 526-553.

XLinguae, Volume 13 Issue 3, June 2020, ISSN 1337-8384, ISSN 2453-711X 
SIMON HOA DALAT. Catechismus Catholicae Ecclesiae. Part 1. Chapter 3. Section 11 "to share in divine life", p. 375. Available online: http://www.simonhoadalat.com/HOCHOI/GIAOLUAT/SachGiaoLyCG/

MainSachGiaoLyCG.html.

TOKAREV, S. A. 1964. The early forms of religion and their development. Moscow:

Politizdat.

TRUONG, T.T.Q. 2020. A Philosophical Assessment of Human Development Approaches and the Vietnamese Experience. In: European Journal of Science and Theology, vol. 16, n. 2, pp. 47-59. ISSN 1841-0464.

TUPHU. 2018. Huong dan cach thuc hau dong va cac nguyen tac chung trong nghi thuc hau dong [Guiding the general principles and ways of performing the mediumship]. Available online: https://viettheatre.com/blog/huong-dan-cach-haudong-va-cac-nguyen-tac-chung-trong-nghi-thuc-hau-dong

VALCO, M. 2018. Global and Local Challenges of the interaction of natural and human sciences. In: European Journal of Science and Theology, vol. 14, n. 5, pp. 1-3. ISSN 1841-0464.

ZALEC, B. - PAVLIKOVA, M. 2019. Civic virtues and functions of religion in public life. In: European Journal of Science and Theology, vol. 15, n. 6, pp. 75-84. ISSN 1841-0464.

Words: 7939

Characters: 48095 (22,72 standard pages)

Thi Thuc Nguyen, Ph.D.

Thanh Hoa University of Culture, Sports and Tourism.

N561, Quang Trung street, Thanhhoa City

Vietnam

bichthuc.dvtdt@gmail.com

Dr. Thi Thanh Quy Truong, PhD.

Hanoi Medical University

N01, Ton That Tung Street, Dong Da District, Hanoi City

Vietnam

truongthanhquyhmu@gmail.com

Nguyen Thi Lan Huong, PhD.

Arts Division of studies Vietnam National Institute of Culture and Arts Studies

N32 Hao Nam Street, Dong Da District. Hanoi City

Vietnam

nguyenlanhuongvicas@gmail.com

Assoc. Prof. Nigina S. Babieva, PhD

Department of Development Psychology

I.M. Sechenov First Moscow State Medical University (Sechenov University)

8 Trubetskaya Street, 119991, Moscow

Russian Federation

n.s.babieva@mail.ru

Prof. Gulnara F. Ruchkina

Head of the Department of Legal Regulation of Economic Activity

Financial University under the Government of the Russian Federation

49 Leningradsky prospect, 125993, Moscow

Russian Federation

gumer@bk.ru 